Division of Geological \& Geophysical Surveys

PRELIMINARY INTERPRETIVE REPORT 2005-3

\title{
PRELIMINARY INVESTIGATION OF THE LISBURNE GROUP, UPPER NANUSHUK RIVER REGION, CENTRAL BROOKS RANGE, ALASKA
}

\author{
by \\ Jesse Garnett White
}

June 2005

\begin{abstract}
THIS REPORT HAS NOT BEEN REVIEWED FOR TECHNICAL CONTENT (EXCEPT AS NOTED IN TEXT) OR FOR CONFORMITY TO THE EDITORIAL STANDARDS OF DGGS.
\end{abstract}

\author{
Released by \\ STATE OF ALASKA \\ DEPARTMENT OF NATURAL RESOURCES \\ Division of Geological \& Geophysical Surveys \\ 3354 College Rd. \\ Fairbanks, Alaska 99709-3707
}

$\$ 3.00$ 



\title{
PRELIMINARY INVESTIGATION OF THE LISBURNE GROUP, UPPER NANUSHUK RIVER REGION, CENTRAL BROOKS RANGE, ALASKA
}

by

Jesse G. White

University of Alaska Fairbanks Department of Geology and Geophysics

Natural Sciences Building, 900 Yukon Drive, PO Box 755780, Fairbanks, AK 99775-5780

\begin{abstract}
The Carboniferous Lisburne Group, a succession of carbonate rocks, has been identified in the Brooks Range Endicott Mountains allochthon, parautochthonous rocks in the northeastern Brooks Range, and in the North Slope subsurface. The Lisburne Group was the original reservoir exploration target in the Lisburne field at Prudhoe Bay. Its importance as both a potential subsurface source and reservoir rock warrants further investigation into the carbonate facies, lithologies, and conodont microfacies for continued correlation with other stratigraphic sections and well data across the Brooks Range and North Slope of Alaska. The Lisburne Group is a potential reservoir target in the National Petroleum Reserve-Alaska and in the Arctic National Wildlife Refuge (ANWR) 1002 Area. The variation in carbonate depositional environments, stratigraphy, facies, and long distances between the western, central, and eastern Brooks Range make correlation of units within the Lisburne difficult.

A total of 1,271 m of Kayak Shale and Carboniferous Lisburne Group outcrop in the central Brooks Range near the headwaters of the Nanushuk River were measured, sampled, and described to gather high-resolution stratigraphic data to better interpret depositional environments and improve stratigraphic correlations with application of conodont biostratigraphy. The Nanushuk River section (Alapah Mountain Section of Armstrong and Mamet, 1978) records marginal marine depositional environments in the uppermost Kayak shale. Carbonate ramp sedimentation began on a marginal marine platform, followed by gradational slope and deep water sediments, followed by continued open marine sedimentation (Armstrong and Mamet, 1978). The section is overlain by the Permian Etivluk Group, Siksikpuk Formation.
\end{abstract}

\section{Introduction}

The purpose of this report is to document preliminary investigation of the Carboniferous Lisburne Group stratigraphy exposed in outcrop in the central Brooks Range along the Nanushuk River, Gates of the Arctic National Park (N 68 10', W 150 45'). Previous investigation of the Alapah Mountain section, located at the headwaters of the Nanushuk River, indicate that the carbonate section is composed of both the Wachsmuth and Alapah limestone, underlain by the Kayak Shale, and overlain by Permian sediments (Armstrong and Mamet, 1978). Lithologic equivalents of the Wahoo Limestone are absent but deeper water time-equivalent rocks may be present, and if so, will have important implications for the paleogeography and tectonics of the region. This preliminary study confirms the general stratigraphy outlined by A.K. Armstrong and B.L Mamet (1978), although the stratigraphic sections vary in their total thicknesses and this study is still ongoing.

Nine days in the summer of 2004 were spent examining outcrop exposed in the Nanushuk River drainage (fig.1). The objective of the study was to obtain an accurate representation of the carbonate stratigraphy and to collect conodont samples for correlation and more precise age control. Previous studies made use of the Mamet foraminiferal zones (Mamet, 1987), but problems with the zones and recent conodont work (Krumhardt, 1992; Krumhardt and others, 
1995; McGee, 2004) in the northeastern Brooks Range have prompted the current undertaking to utilize conodont biostratigraphy to refine age control. The resulting composite stratigraphic section (four outcrop field sections) was measured using a Jacob's staff and Brunton compass. Marker beds were used to correlate the four sections. Lithologic samples were collected approximately every $15 \mathrm{~m}$. Lithofacies are based on outcrop descriptions (this paper). Conodont samples were collected in wackestone and packstone that contain relatively abundant visible faunal elements. All samples were collected and keyed to the measured stratigraphic sections. The Dunham (1962) and Embry and Klovan (1971) schemes for classification of carbonate rocks according to depositional texture were employed in the field and during lab analysis. Seventeen conodont samples and 55 lithologic samples were collected. Forty-nine thin sections and lithologic samples have been stained with Alizarin red-S to differentiate between dolomite and calcite and are currently under analysis.

\section{Regional Geology}

The Carboniferous Lisburne Group (figs. 12-14) is a thick carbonate ramp succession (60$1,500 \mathrm{~m}$ ) that was deposited on a slowly subsiding south facing/east trending (Bowsher and Dutro, 1957) continental margin (Watts and others, 1995). It represents a carbonate ramp that generally deepens from northeast to southwest (Armstrong and Mamet, 1978; Watts and others, 1995). These carbonate rocks conformably overlie the Kayak Shale of the Endicott Group (Armstrong and Mamet, 1977), the first depositional sequence that lapped over the subMississippian unconformity during the initial phases of passive margin subsidence (Watts and others, 1995). The Endicott and Lisburne groups make up a transgressive megacycle within the Ellesmerian sequence that was first defined by Lerand (1973) in the Canadian Arctic. The Ellesmerian sequence is conformable with the overlying Brookian sequence in the North Slope subsurface (Moore and others, 1994).

The early Mississippian marginal marine Kayak Shale is named for Kayak Creek, which joins Alapah Creek south of Shainin Lake (Bowsher and others, 1957). It is the uppermost member of the Endicott Group. It both disconformably overlies the paralic Kanayut Conglomerate (Chapman and others, 1964) and underlies the Wachsmuth Limestone (Brosgé and others, 1962) in the central Brooks Range. The early Mississippian age is based on revised megafossil zonations (Dutro, 1987). The Kayak Shale contact is time transgressive with the Lisburne Group and is thought to represent deposition within estuaries (LePain, 1993). It is typically a black shale and siltstone with lesser interbedded sandstone and limestone. The limestone interbeds and associated fauna indicate normal marine conditions existed during Kayak deposition. Prior to the onset of carbonate sedimentation, the Kayak maintained a restricted circulation due to possible carbonate barriers (Watts and others, 1995). Transgressive carbonate sedimentation began intermittently within the Kayak Shale (these limestone beds are part of the Kayak) and gradually took hold as Lisburne Group deposition began. The basal contact of the Lisburne Group is recognizable where a yellow-weathering cliff-forming unit of the Wachsmuth Limestone lies above the recessive Kayak Shale (fig. 3A).

The early Mississippian Lisburne Group is exposed in the foreland fold-and-thrust belt of the Brooks Range (Dumoulin and others, 1992) in what is known as the Endicott Mountains allochthon (Mull and others, 1987) and is a component of a larger carbonate system throughout the North American Cordillera and in eastern Russia (Armstrong and Bird, 1976). It is also present in the North Slope subsurface including the Prudhoe Bay area (Bird and Jordan, 1977). In the Nanushuk River drainage the Lisburne comprises the Wachsmuth and Alapah limestone units, originally defined near Shainin Lake (Bowsher and Dutro, 1957), and overlain by Permian rocks of the Etivluk Group. In the western and far western Brooks Range, the Lisburne-age rocks are represented by the predominantly deep marine Kuna Formation of the Endicott Mountains 
allochthon. The Kuna consists of black carbonaceous shale, black chert, fine-grained limestone, and dolostone and may have potential for natural gas (Dumoulin and others, 1992; Banet and Evans, 2002). The Kuna Formation occupies the same stratigraphic position as carbonate rocks of the Wachsmuth and Alapah limestones to the east (Moore and others, 1994). The Kuna Formation hosts the strata-bound zinc-lead-silver deposit of the Red Dog Mine in the De Long Mountains Quadrangle (Moore and others, 1986). In the northeastern Brooks Range, the Lisburne Group parautochthon is composed of Alapah and Wahoo limestones. The Wachsmuth has been recently interpreted in the central-eastern Brooks Range by McGee (2004). The bases of the Mississippian-Pennsylvanian limestone units are progressively younger from the southeast to the northeast across the Brooks Range (Armstrong and Mamet, 1970).

The Wachsmuth Limestone in the central Brooks Range is considered early and late Mississippian in age (Osagean to Meramecian) based on revised megafossil zonations (Dutro, 1987). It is divided into four informal members (ascending): Shaly limestone, crinoidal limestone, dolomite, and banded chert-limestone (Bowsher and Dutro, 1957). The composite type section at Mount Wachsmuth and Sugarloaf Hill near Shainin Lake has a total thickness of 375 m overlying the Kayak Shale and underlying the Alapah Limestone (Bowsher and Dutro, 1957).

The Alapah Limestone forms the upper part of the Lisburne Group in the central Brooks Range. At the type locality near Shainin Lake, it is divided into nine informal members (ascending): Shaly limestone, dark limestone, platy limestone, banded limestone, black chertshale, light-gray limestone, fine-grained limestone, chert-nodule, and upper limestone (Bowsher and Dutro, 1957). The total thickness is $296 \mathrm{~m}$ as described in measured sections at the type locality. The upper contact is a Holocene erosional surface in the Shainin Lake area but the Lisburne Group is overlain by the Permian Siksikpuk Formation in the Nanushuk River drainage. The Alapah is late Mississippian based on lithostrotionoid corals, productid brachiopods, and revised megafossil zonations (Bowsher and Dutro, 1957).

Dumoulin and others' (1997) study of the Shainin Lake section concludes that the Wachsmuth and Alapah limestones are as thick as $708 \mathrm{~m}$ and that the Wachsmuth $(480 \mathrm{~m})$ comprises extensive intervals of dolomitized cross-bedded skeletal grainstone. The Alapah (228 $\mathrm{m}$ ) is primarily skeletal grainstone and coralline boundstone deposited in an open marine environment adjacent to skeletal sand shoals (Dumoulin, 1997).

In the central Brooks Range, specifically the Chandler Lake Quadrangle, the Lisburne is overlain by the Permian Siksikpuk Formation, part of the Etivluk Group (Mull and others, 1982, 1987b).

\section{Field Data and Preliminary Interpretation}

The field area is located along the headwaters of the Nanushuk River in the central Brooks Range within Gates of the Arctic National Park (fig. 1). Field data collected from the Kayak Shale and Lisburne Group at the headwaters of the Nanushuk River include: 1,271 m measured in four partial sections, 55 lithologic samples, and 17 conodont samples. Only the top $126 \mathrm{~m}$ of the Kayak Shale was measured. For this study only the major units have been defined; further subdivisions will require additional research.

The Kayak Shale (fig. 2) in the area investigated is primarily fissile argillaceous paper shale repetitively interbedded with sandstone and limestone (LePain, 1993). The sandstone units are generally fining-upward medium-grained quartzose sandstone containing mud clasts approximately $1-5 \mathrm{~cm}$ in diameter. Much of the sandstone weathers a tan/brown with gray argillaceous partings. The limestone is predominantly pelmatozoan-brachiopod-bryozoan-coral wackestone to packstone that weather brown/yellow to light gray (fig. 2C). Bioclastic mudstone, grainstone, and rare rudstone are also present. The limestone beds are interbedded with fetid, 
white-light gray calcareous shale up to $3 \mathrm{~m}$ thick. Several intervals of weathered shale and rubble crop up to $22 \mathrm{~m}$ thick are common in the upper Kayak (fig. 3A). Rare limestone hardgrounds were documented in reddish-orange weathering 1-3 cm beds with horizontal bedding plane trace fossils (fig. 2A). Overall the limestone beds thicken upsection within the Kayak Shale and transition to the Wachsmuth Limestone, a distinctive yellowish brown cliffforming unit (fig. 3A). The Kayak-Lisburne contact is gradational and was placed at the first thick limestone bed above the last thick shale unit. LePain (1993) regards the upper Kayak Shale as representing a marginal to shallow marine environment.

The total thickness of the Wachsmuth Limestone (figs. 1-6) at the Nanushuk River is approximately $413 \mathrm{~m}$. This thickness is comparable to the Shainin Lake sections of Bowsher and Dutro (1957) at $375 \mathrm{~m}$ and Dumoulin and others (1997) at $480 \mathrm{~m}$. The Wachsmuth Limestone contains thick, coarsely crystalline, coarsening-upward intervals of primarily pelmatozoan wackestone to grainstone with a minor brachiopod-bryozoan-coral component (fig. 3E). These intervals weather yellow to tan in color and are mostly dolomitized. Nodular, elongate, and lesser laminated chert beds or thin-bedded argillaceous mudstone to packstone are also present as interbeds (fig. 3D). Sedimentary structures, although rare in Wachsmuth outcrop, include intraclasts (fig. 3B), bioclastic and non-bioclastic cross-bed sets, and hummocky cross stratification. The bedding is parallel to undulate with rare pinch and swell features (fig. 4A). Dolomitized beds are typically fractured (fig. 3C) and sometimes exhibit intercrystalline porosity and stylolites. Diagenetic dissolution features include wispy, blocky, and jagged stylolites.

The Wachsmuth-Alapah contact (figs. 6A, 12) is transitional and begins with a notable increase in chert, pelmatozoan-coral-bryozoan grainstone, and colonial corals bounded by grainstone and a decrease in argillaceous thin bedded limestone.

The relatively resistant Alapah Limestone (figs. 6-11) was measured to a thickness of $858 \mathrm{~m}$ (figs. 11D-E). The Alapah is broadly characterized by nodular, elongate, and microlaminated vitreous black chert, thin-bedded siliceous mudstone and shale, homogenous pelmatozoanbryozoan grainstone, pelmatozoan-bryozoan-brachiopod mudstone and wackestone, and local brachiopod rudstone. Isolated coralline boundstone alternating with grainstone are common (fig 6A).

Much of the lower Alapah is mudstone, silicified mudstone, and chert with interbedded limestone/dolostone lithologies. The chert of the lower Alapah (figs. 6-8) is thinly bedded (1-20 $\mathrm{cm})$ black, dark gray, and locally brown. Chert lithologies are uniform and monotonous or interbedded with dolostone (figs. 6B-C). It has been interpreted to have been deposited as partly pelagic sediments in an anoxic starved basin to the south of the main shelf carbonates of the Lisburne (Armstrong and Mamet, 1978). The middle Alapah (figs. 7-10) is characterized and dominated by $5-10-\mathrm{m}$ repetitive packages of chert and fine- to coarse-grained dolo-grainstones (fig. 8A). The chert varies in overall percentage and ranges from bedded, elongate, to nodular type forms. The bedded chert is typically irregular and thin, on the order of $2-20 \mathrm{~cm}$ thick. The upper Alapah (fig. 11) is a thick to massive light gray pelmatozoan-bryozoan-brachiopod mudstone to grainstone. The grainstone lithologies of the upper Alapah typically lack significant amounts of chert. Possible coral bioherms or patch reefs within the upper Alapah have been identified at 1,070 $\mathrm{m}$ (figs. 11B-C). A complete section was not established in the 2004 field season due to structural complexities (figs. 11D-E). The section will be completed in the summer of 2005 to incorporate the remaining Alapah and overlying Permian sediments. The Permian Siksikpuk Formation was observed overlying the Alapah Limestone at the Nanushuk River in the core of a syncline on Cockedhat Mountain (figs. 11E, 15). 


\section{Discussion}

The Lisburne Group has been identified by many workers to have been deposited as a ramp succession. Carbonate ramps can be tens to hundreds of kilometers long with a slope of about 1 degree that gradually passes into a basin with no significant break in slope (Ahr, 1973). They are characterized by low carbonate productivity (Elrick and Read, 1991) and are known from a variety of tectonic settings typically developing along passive margins and foreland basins dominated by flexural subsidence (Burchette and Wright, 1992). Ramps can be divided into inner ramp, mid ramp, and outer ramp components comprising a variety of depositional environments. In general, the Lisburne Group in the western and central Brooks Range has been recognized as shallow marine, slope, toe of slope, and euxinic basin deposits (Armstrong and Mamet, 1978; Armstrong and Mamet, 1989; Dumoulin and others, 1993). The Nanushuk River section has been observed to be in the same categories ranging largely from middle to outer ramp.

The Lisburne Group is typically subdivided on the basis of large-scale weathering patterns and facies (Watts and others, 1995; McGee, 2004). The lower Wachsmuth Limestone is interpreted as being deposited in a shallow marine open-platform to restricted-platform environment based on lithology and the transitional contact with the Kayak Shale. The middle Wachsmuth is interpreted to be open-platform to near shoaling-water shelf deposition based on lithology, sedimentary structures, fossil evidence, and the work of Armstrong and Mamet (1978). The upper Wachsmuth is interpreted to represent an open marine shelf to foreslope depositional environment based on lithology with the uppermost Wachsmuth representing the beginnings of an anaerobic starved basin evidenced by regularly bedded black chert, black siliceous shale, and dark gray thin-bedded dolomite.

Armstrong and Mamet (1978) divide the Wachsmuth into two different lithologic units at the Nanushuk River. A lower, massive, light gray argillaceous limestone and an upper, thinnerbedded argillaceous limestone containing black nodular chert for a total of $364 \mathrm{~m}$. Their Wachsmuth-Alapah contact is within a $12 \mathrm{~m}$ unit of medium-bedded gray bryozoanechinoderm-ostracode-foraminiferal packstone (Armstrong and Mamet, 1978). Bowsher and Dutro (1957) place the Wachsmuth-Alapah contact between a banded chert and limestone and shaly limestone at Shainin Lake. Watts and others (1995) place the contact at Shainin Lake between thick intervals of cross-bedded, pelmatozoan-skeletal grainstone and coralline boundstone alternating with pelmatozoan grainstone.

The current study places the Wachsmuth-Alapah contact (fig. 6) within a 17-m coarseningupward mudstone to grainstone interval at $413 \mathrm{~m}$. The beds are 1.0-1.5 m thick between covered intervals. The top of the 17-m package is pelmatozoan-coral grainstone underlain by pelmatozoan-brachiopod mudstone to grainstone with elongate chert nodules. Because the contact is transitional, placing the contact can be difficult and in some cases the actual contact may be covered. The lithologic transition between the two units is recognizable in outcrop photographs (fig. 12).

The Alapah Limestone is interpreted to be rhythmically transitional (cyclic) from basinal euxinic environments to toe-of-slope and foreslope carbonate depositional environments and finally open-marine near shoaling environments (Armstrong and Mamet, 1978). This is evidenced by the repetitive facies transitions from laminated chert and mudstone to wackestone, packstone, and grainstone.

\section{Conclusions and Future Work}

The Lisburne Group changes (northeast-southwest) from a carbonate ramp to basin across northern Alaska. It has been interpreted as representing a passive margin sequence by previous authors including Watts, et al., 1995 and Eckstein, M.K., 1994. The Nanushuk River section is 
notably thicker compared with most sections to the east. Preliminary data imply a significant change in subsidence history between the two areas during the middle to late Mississippian. The current study will help document the petroleum potential of the Lisburne Group and test the hypothesis that it was deposited along a simple passive margin. Variations in subsidence rate may indicate tectonic control of accumulation and will have important implications for understanding potential oil and gas reserves in the subsurface north of the central Brooks Range, stratigraphic correlation, and the Carboniferous paleogeography of northern Alaska.

Future field work should involve detailed stratigraphic analysis and closely spaced conodont sampling for more accurate age control and correlation value. The Kayak Shale-Wachsmuth, Wachsmuth-Alapah transitional zones, and the Alapah Limestone-Permian Siksikpuk contact (fig. 15) should be heavily sampled for both lithology and conodonts. The entire Nanushuk River section will also need to be further subdivided into carbonate ramp to basin systems tracts for comparison with other sections. Future research should involve regional Lisburne Group outcrop and subsurface stratigraphy and correlation. Geologic tools that could be implemented and incorporated into the study include North Slope well logs, seismic lines, and laboratory methods including cathodoluminescence and scanning electron microscopy.

\section{Acknowledgments}

I thank the following institutions for their generous and stable support in my education and in writing this document: University of Alaska Fairbanks Geology and Geophysics Department, specifically the Tectonics and Sedimentation Research Group, and the Department of Natural Resources, Alaska Division of Geological \& Geophysical Surveys for funding and helicopter support. Without UAF Geology and ADGGS this project would not have been possible. Thanks also to Dr. Mike Whalen and Jim Clough for hours of intellectual conversation on carbonate research, tectonics, basin research, and general geology; Andrea Krumhardt for her generosity, conodont identification, and endless smiles; my committee members Dr. Mike Whalen, Dr. Paul McCarthy, and Dr. Bernard Coakley for support in writing grant proposals; and Mike Hayes for working as my field assistant in mosquito-infested terrain. Of special mention are the peer reviewers of this publication, Dr. Mike Whalen and Jim Clough, and the editor, Paula Davis.

\section{References Cited}

Ahr, W.M., 1973, The carbonate ramp: An alternative to the shelf model: Transactions of the Gulf Coast Association of Geological Sciences, v. 23, p. 221-225.

Armstrong, A.K., 1974, Carboniferous carbonate depositional models, preliminary lithofacies, and paleotectonic maps, Arctic Alaska: American Association of Petroleum Geologists Bulletin, v. 58, p. 621-645.

Armstrong, A.K., and Bird, K.J., 1976, Carboniferous environments of deposition and facies Arctic Alaska, Symposium on Recent and Ancient Sedimentary Environments in Alaska, Anchorage, Alaska Geological Society Symposium Proceedings, p. A1-A16.

Armstrong, A.K., and Mamet, B.L., 1977, Carboniferous microfacies, microfossils, and corals, Lisburne Group, Arctic Alaska. U.S. Geological Survey Professional Paper 849, 144 p.

Armstrong, A.K., and Mamet, B.L., 1978, Microfacies of the Carboniferous Lisburne Group, Endicott Mountains, Arctic Alaska, in Stelk, C.R., and Chatterton, B.D.E., eds., Western and Arctic Canadian Biostratigraphy: Geological Association of Canada Special Paper 18, p. 333-394.

Armstrong, A.K., and Mamet, B.L., 1970, Biostratigraphy and dolomite porosity trends of the Lisburne Group, in Adkinson, W.L., and Brosgé, M.M., eds., Proceedings of the geological 
seminar on the North Slope of Alaska: American Association of Petroleum Geologists Pacific Section Meeting, Los Angeles, p. N1-N15.

Banet, A.C., and Evans, K.R., 2002, Paleo source-rock characteristics of the Kuna Formation in the western Brooks Range [abs]: American Association of Petroleum Geologists Bulletin, v. 86, p. 1135.

Bird, K.J., and Houseknecht, D.W., 2002, U.S. Geological Survey 2002 petroleum resource assessment of the National Petroleum Reserve in Alaska (NPRA): Play maps and technically recoverable resource estimates: U.S. Geological Survey Open-File Report 02-207, 18 p.

Bird, K.J., and Jordan, C.F., 1977, Lisburne Group (Mississippian and Pennsylvanian), potential major hydrocarbon objective of Arctic Slope, Alaska: American Association of Petroleum Geologists Bulletin, v. 61, p. 1493-1512.

Bowsher, A.L., and Dutro, J.T., Jr., 1957, The Paleozoic section in the Shainin Lake area, central Brooks Range, Alaska, in Exploration of Naval Petroleum Reserve No. 4 and adjacent areas, northern Alaska, 1944-53; Part 3, Areal geology: U.S. Geological Survey Professional Paper 303-A, p. A1-A39.

Brenckle, Paul L., 1990, Foraminiferal division of the lower Carboniferous/Mississippian in North America, in Brenckle, P.L., and Manger, W.L., eds., Intercontinental correlation and division of the Carboniferous System; contributions from the Carboniferous Subcommission meeting, Courier Forsch.- Inst. Senckenberg, v. 130, p. 65-78.

Brosgé, W.P., Dutro, J.T., Jr., Mangus, M.D., and Reiser, H.N., 1962, Paleozoic sequence in eastern Brooks Range, Alaska: American Association of Petroleum Geologists Bulletin, v. 46, no. 12 , p. 2174-2198.

Burchette, T.P., and Wright, V.P., 1992, Carbonate ramp depositional systems: Sedimentary Geology, v. 79, p. 3-57.

Chapman, R.M., Detterman, R.L., and Marvin, D.M., 1964, Geology of the Killik-Etivluk rivers region, Alaska, in Exploration of Naval Petroleum Reserve No. 4 and adjacent areas, northern Alaska, 1944-53; Part 3, Areal geology: U.S. Geological Survey Professional Paper 303-F, p. F325-F407.

Churkin, M., Jr., 1973, Paleozoic and Precambrian rocks of Alaska and their role in its structural evolution: U.S. Geological Survey Professional Paper 740, 64 p.

Detterman, R.L., 1970, Sedimentary history of the Sadlerochit and Shublik formations in northeastern Alaska, in Adkison, W.L., and Brosgé, M.M., eds., Proceedings of the geological seminar on the North Slope of Alaska: American Association of Petroleum Geologists, Pacific Section, p. O1-O13, Prepared in conjunction with the Northern California Geological Society and U.S. Geological Survey.

Dutro, J.T., Jr., 1987, Revised megafossil biostratigraphic zonation for the Carboniferous of northern Alaska, in Tailleur, I.L., and Weimer, Paul, eds., Alaskan North Slope Geology; Volume 1: Society of Economic Paleontologists and Mineralogists, Pacific Section, book 50, North Slope Seminar II, AAPG/SEPM/SEG Pacific Section Annual Meeting, Anchorage, AK, May 22-24, 1985, p. 359-364, Prepared by Society of Economic Paleontologists and Mineralogists, Pacific Section, and Alaska Geological Society.

Dumoulin, J.A., 1999, Carboniferous and older carbonate rocks: Lithofacies, extent, and reservoir quality, in The Oil and Gas Potential of the Arctic National Wildlife Refuge 1002 Area, Alaska: U.S. Geological Survey Open-File Report 98-34, p. CC1-CC50.

Dumoulin, J.A., Harris, A.G., and Schmidt, J.M., 1993, Deep-water lithofacies and conodont faunas of the Lisburne Group, west-central Brooks Range, Alaska, in Dusel-Bacon, Cynthia, and Till, A.B., eds., Geological Studies in Alaska by the U.S. Geological Survey: U.S. Geological Survey Bulletin 2068, p. 31-47. 
Elrick, M., and Read, J.F., 1991, Cyclic ramp-to-basin carbonate deposits, lower Mississippian, Wyoming and Montana: A combined field and computer modeling study: Journal of Sedimentary Petrology, v. 61, p. 1194-1224.

Eckstein, M.K., 1994, Evolution of a mid-Paleozoic carbonate ramp in the northeastern Brooks Range, Alaska: The Lisburne Group (Carboniferous) along the Aichilik River transit: M.S. thesis, University of Alaska, Fairbanks, 203. p.

Houseknecht, D.W., and Bird, K.J., 2002, The 1998 USGS petroleum resource assessment of the Arctic National Wildlife Refuge 1002 area and adjacent waters: American Association of Petroleum Geologists Pacific Section Meeting Abstracts, v. 86, p. 1146.

Keller, A.S., Morris, R.H., and Detterman, R.L., 1961, Geology of the Shaviovik and Sagavanirktok rivers region, Alaska, in Exploration of Naval Petroleum Reserve No. 4 and adjacent areas, northern Alaska, 1944-53; Part 3, Areal geology: U.S. Geological Survey Professional Paper 303-D, p. D169-D222.

Leffingwell, E. de K., 1919, The Canning River region, northern Alaska: U.S. Geological Survey Professional Paper 109, $251 \mathrm{p}$.

LePain, D.L., 1993, Transgressive sedimentation in rift-flank region: Deposition of the Endicott Group (Early Carboniferous), northeastern Brooks Range, Alaska: Fairbanks, University of Alaska, Ph.D dissertation, $325 \mathrm{p}$.

Mamet, B.L., and de Batz, R., 1987, Carboniferous microflora, Lisburne Group, Sadlerochit Mountains, Alaska: $11^{\text {th }}$ International Congress of Carboniferous Stratigraphy and Geology, p. 50-60.

McGee, Michelle M., 2004, Carboniferous Lisburne Group carbonates of the Porcupine Lake Valley: Implications for surface to subsurface sequence stratigraphy, paleogeography, and paleoclimatology: Fairbanks, University of Alaska, Ph.D dissertation, 454 p.

Montgomery, S.L., 2003, Alaska's ANWR; 2, Geological Assessment and production forecasts for the ANWR 1002 Area: Oil and Gas Journal, v. 101, p. 35-40.

Moore, T.E., Wallace, W.K., Bird, K.J., Karl, S.M., Mull, C.G., and Dillon, J.T., 1994, Geology of northern Alaska, in Plafker, G., and Berg, H.C., eds., The Geology of Alaska: Boulder, Colorado, Geological Society of America, The Geology of North America, v. G-1, p. XX$\mathrm{XX}$.

Moore, D.W., Young, L.E., Modene, J.S., and Plahuta, J.T., 1986, Geologic setting and genesis of the Red Dog zinc-lead-silver deposit, western Brooks Range, Alaska: Economic Geology, v. 81, p. 1696-1727.

Mull, C.G., Tailleur, I.L., Mayfield, C.F., Ellersiek, I.F., and Curtis, S., 1982, New upper Paleozoic and lower Mesozoic stratigraphic units, central and western Brooks Range, Alaska: American Association of Petroleum Geologists Bulletin, v. 66, p. 348-362.

Mull, C.G., Crowder, R.K., Adams, K.E., Siok, J.P., Bodnar, D.A., Harris, E.E., and Alexander, R.A., 1987b, Stratigraphy and structural setting of the Picnic Creek allochthon, Killik River Quadrangle, central Brooks Range, Alaska: A summary, in Tailleur, I., and Weimer, P., eds., Alaskan North Slope geology: Bakersfield, California, Society of Economic Paleontologists and Mineralogists, Pacific Section, and Alaska Geological Society, Book 50, p. 649-662.

Watts, K.F., Harris, A.G., Carlson, R.C., Eckstein, M.K., Gruzlovic, P.D., Imm, T.A., Krumhardt, A.P., Lasota, D.K., Morgan, S.K., Dumoulin, J.A., Enos, P, Goldstein, R.H., and Mamet, B.L., 1995, Analysis of reservoir heterogeneities due to shallowing-upward cycles in carbonate rocks of the Pennsylvanian Wahoo Limestone of northeastern Alaska, Final Report for 1989-1992 (DOE/BC/14471-19), Bartlesville Project Office, 433 p. 


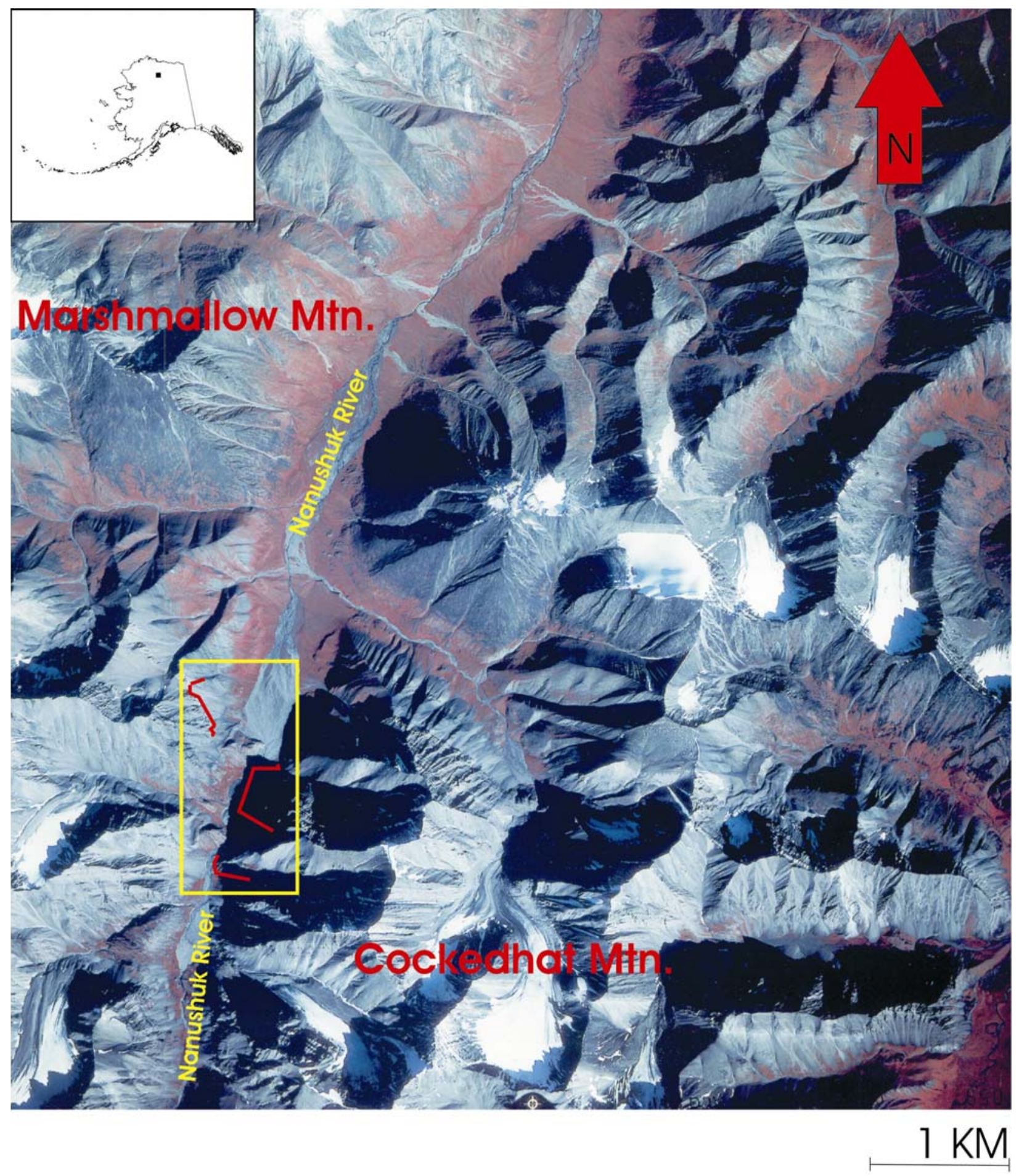

Figure 1: Aerial Photograph of the Upper Nanushuk and location of measured sections.

- Red Lines are measured sections 


\begin{tabular}{|c|c|c|c|c|c|c|}
\hline \multicolumn{5}{|c|}{ LITHOLOGY } & \multicolumn{2}{|r|}{ SKELETAL GRAINS } \\
\hline & Mudstone & & Floatstone & $\Delta$ & \multirow[t]{3}{*}{ Chert } & Af Bryozoan (Fenestrate) \\
\hline & Mud-wack & & \multirow{2}{*}{\multicolumn{2}{|c|}{ Rudstone }} & & $\begin{array}{ll}0 & \text { Brachiopod } \\
\theta & \text { Ostracod }\end{array}$ \\
\hline & & & & & & $\& \quad$ Foraminifera \\
\hline & Wackestone & $=0$ & \multicolumn{2}{|c|}{ Calcareous Shale } & & $\begin{array}{l}\text { Sponge Spicules } \\
\text { Colonial Coral }\end{array}$ \\
\hline & Wack-pack & & \multicolumn{2}{|l|}{ Dolostone } & & (1) Solitary Coral \\
\hline & Packstone & & \multicolumn{2}{|l|}{ Sandstone } & & Bioclast (undifferentiated) \\
\hline I & Pack-grain & $y$ & \multicolumn{2}{|c|}{ Calcareous Sand } & & (1) Calcisphaera sp. \\
\hline & Grainstone & 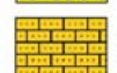 & \multicolumn{2}{|c|}{ Sandy Limestone } & & Bivalve \\
\hline \multirow{2}{*}{\multicolumn{5}{|c|}{ SEDIMENTARY STRUCTURES }} & & ^ Asphaltina sp. \\
\hline & & & & & & A Donezella sp. \\
\hline \multicolumn{5}{|c|}{ 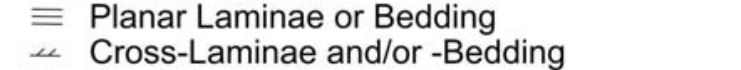 } & & NON-SKELETAL GRAINS \\
\hline « $\mathrm{H}$ & \multirow{2}{*}{\multicolumn{4}{|c|}{$\begin{array}{l}\text { Herringbone Cross-Laminae } \\
\text { and/or -Bedding }\end{array}$}} & & $\odot$ Ooid \\
\hline \multirow{2}{*}{\multicolumn{2}{|c|}{ \% Graded Bedding }} & & & & & () Oncolite \\
\hline$\sim 1$ & & & & & & - Peloid \\
\hline \multicolumn{5}{|c|}{$\approx$ Wavy Laminae } & & $\Sigma$ Intraclast \\
\hline \multirow{2}{*}{\multicolumn{5}{|c|}{$\begin{array}{l}\text { W Crinkly Laminae } \\
\text { ¿ High-Angle Cross-Bedding }\end{array}$}} & & qtz Detrital Quartz \\
\hline & & & & & \multicolumn{2}{|r|}{ ABBREVIATIONS } \\
\hline \multirow{5}{*}{ 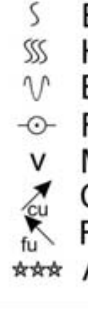 } & \multirow{5}{*}{\multicolumn{4}{|c|}{$\begin{array}{l}\text { Bioturbated } \\
\text { Highly Bioturbated } \\
\text { Burrow Structure } \\
\text { Fenestral Fabric } \\
\text { Mudcracks } \\
\text { Coarsening-Upward } \\
\text { Fining-Upward } \\
\text { Articulated Crinoid Stems }\end{array}$}} & & RP Restricted Platform \\
\hline & & & & & & OP Open Platform \\
\hline & & & & & & SH Shoal \\
\hline & & & & & & $\begin{array}{l}\text { AWB Open Marine Above Fair- } \\
\text { Weather Wave Base }\end{array}$ \\
\hline & & & & & & $\begin{array}{l}\text { BWB Open Marine Below Fair- } \\
\text { Weather Wave Base }\end{array}$ \\
\hline
\end{tabular}

Key to symbols: Lithology, Sedimentary structures, and grains 


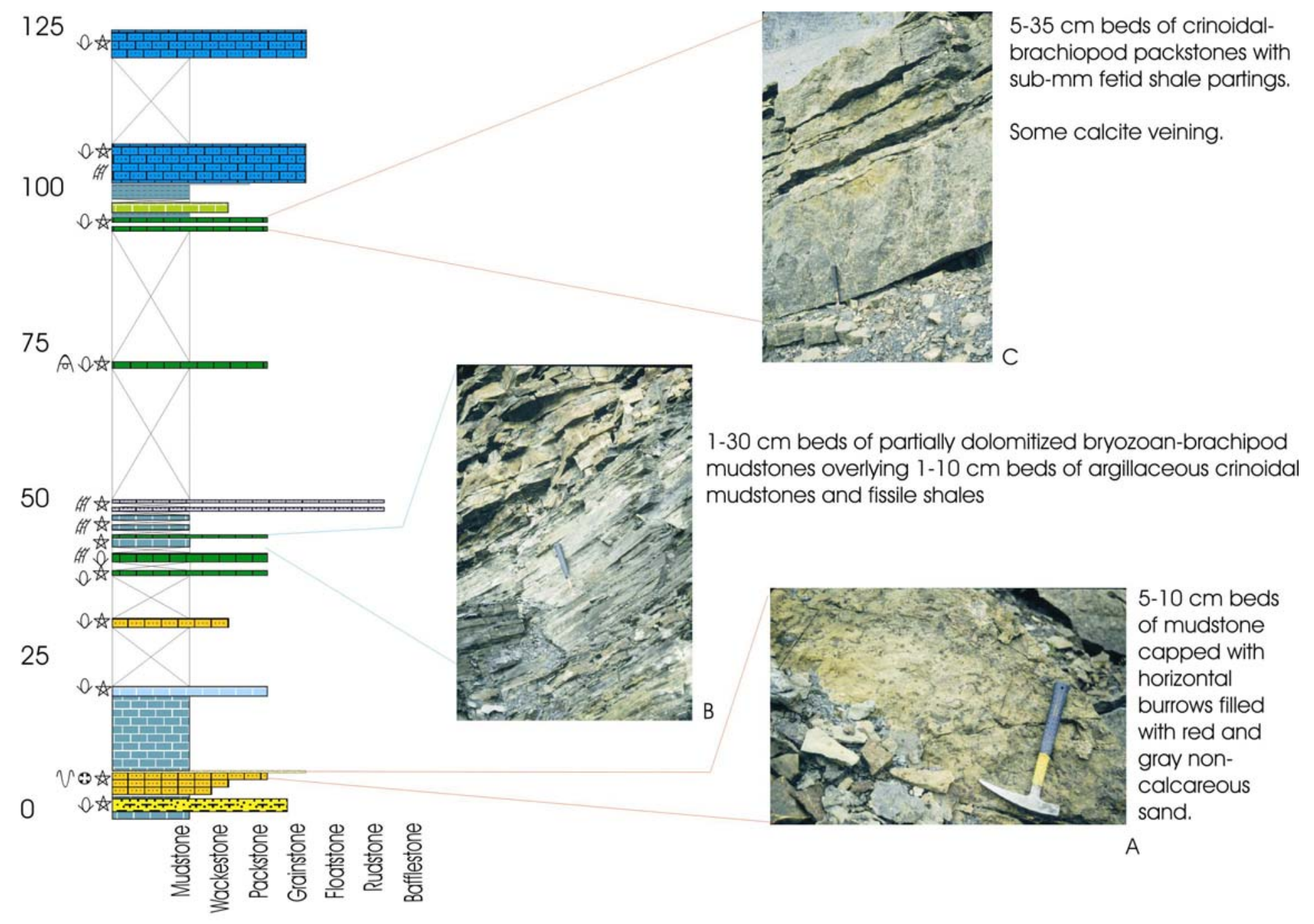

Fig. 2: Kayak Shale and initiation of Wachsmuth Limestone 


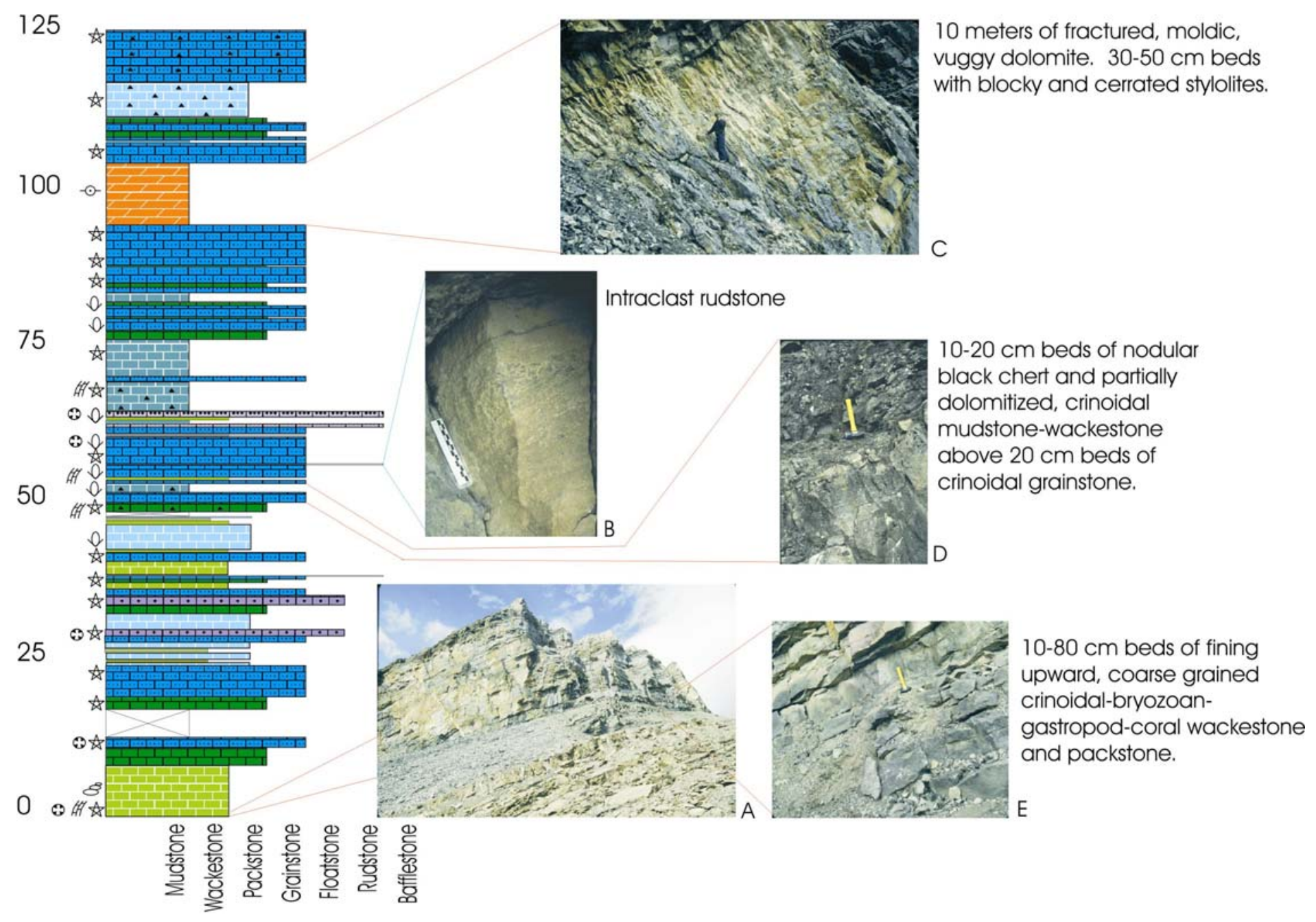

Fig. 3: Lower Wachsmuth Limestone 


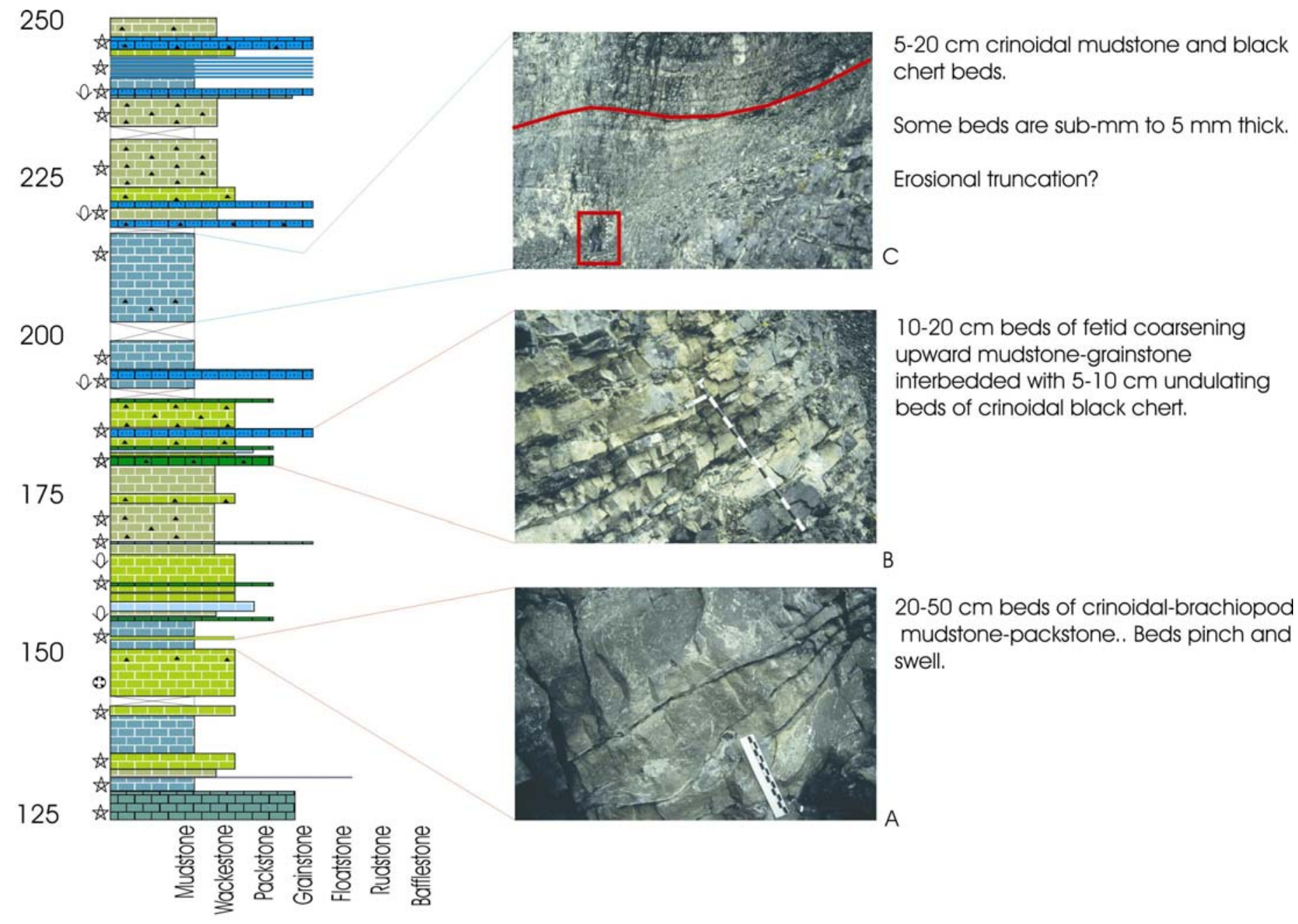

Fig. 4: Middle Wachsmuth Limestone 


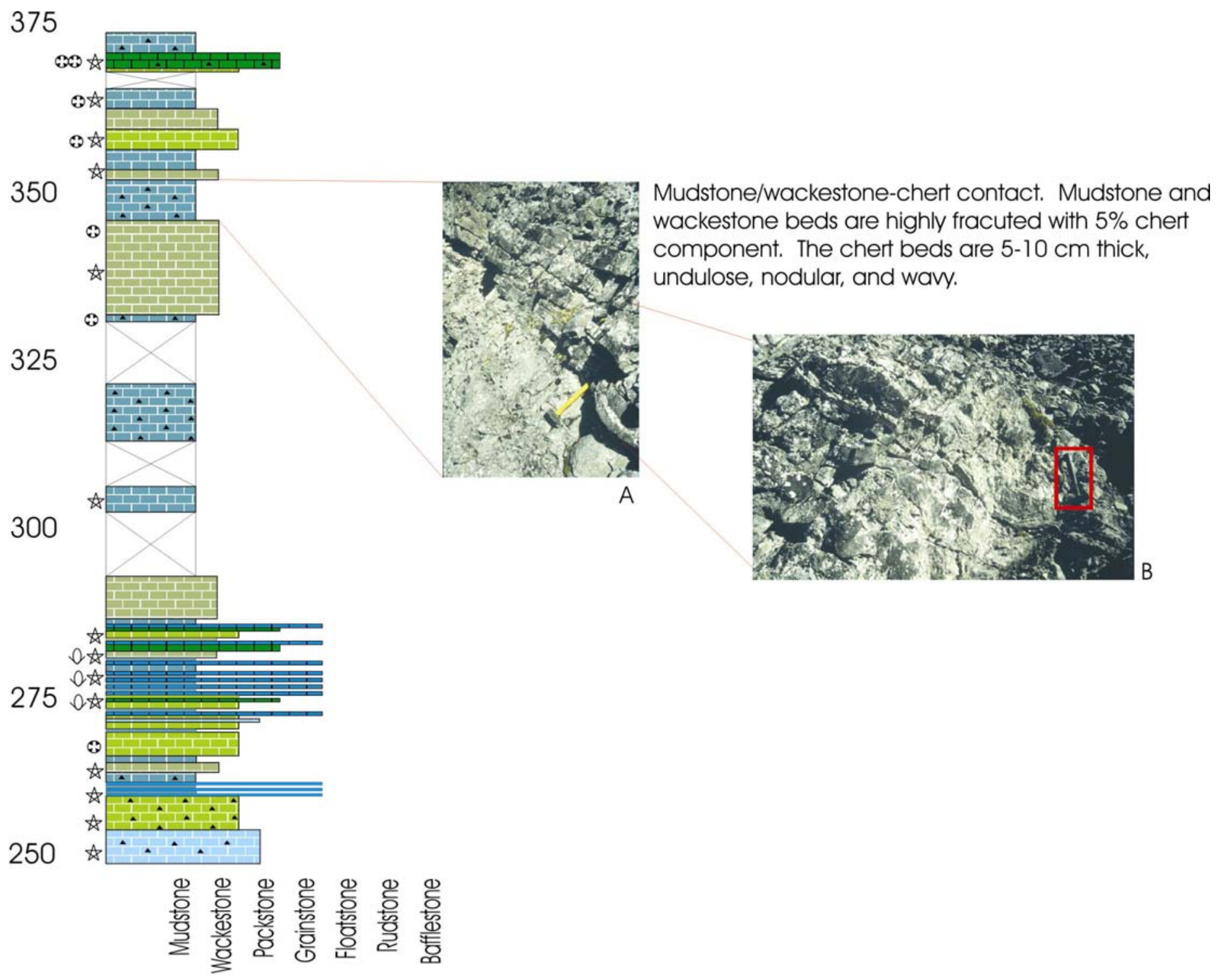

Fig. 5: Upper Wachsmuth Limestone 


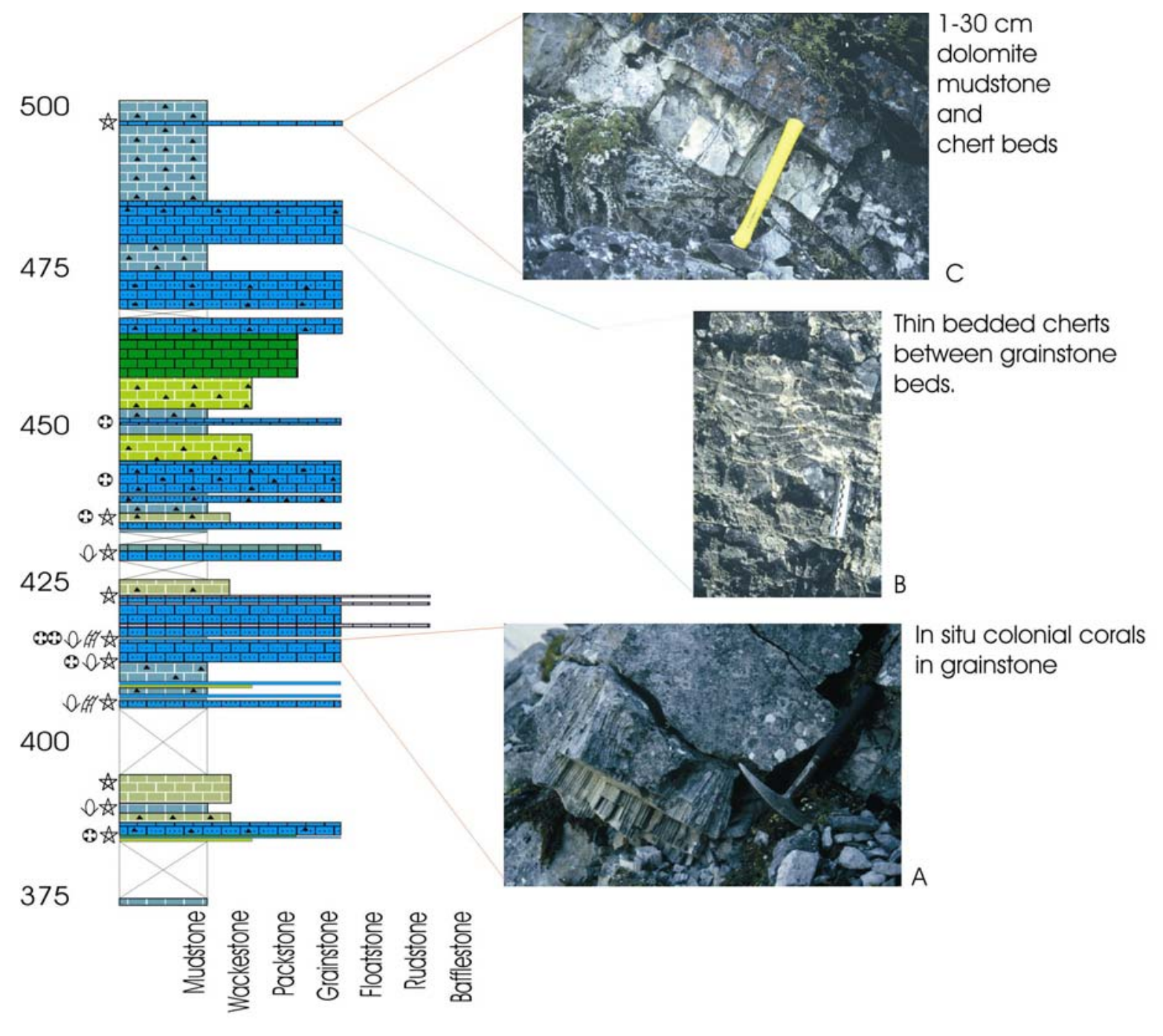

Fig. 6: Upper Wachsmuth and Lower Alapah Limestone 


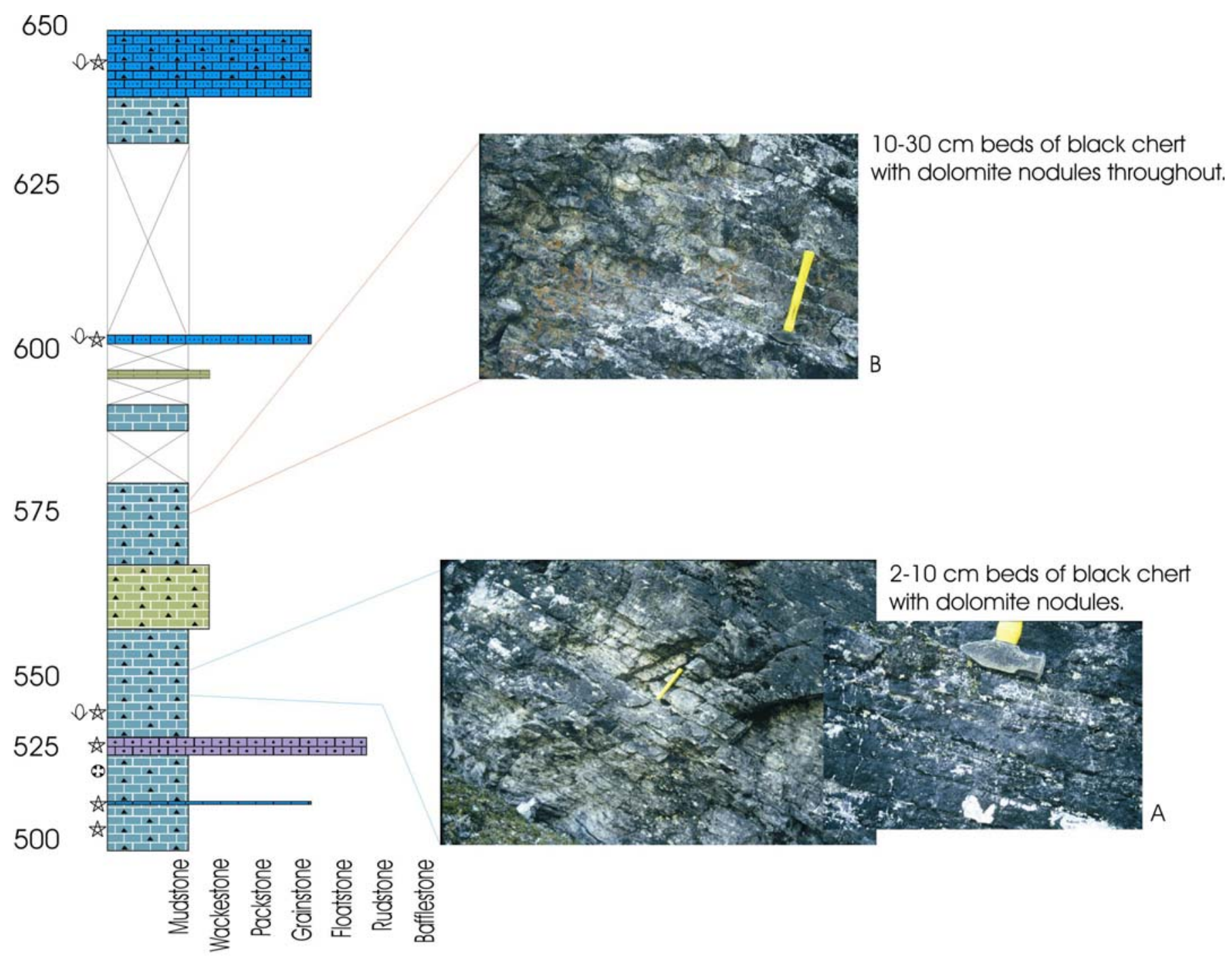

Fig. 7: Lower Alapah Limestone 


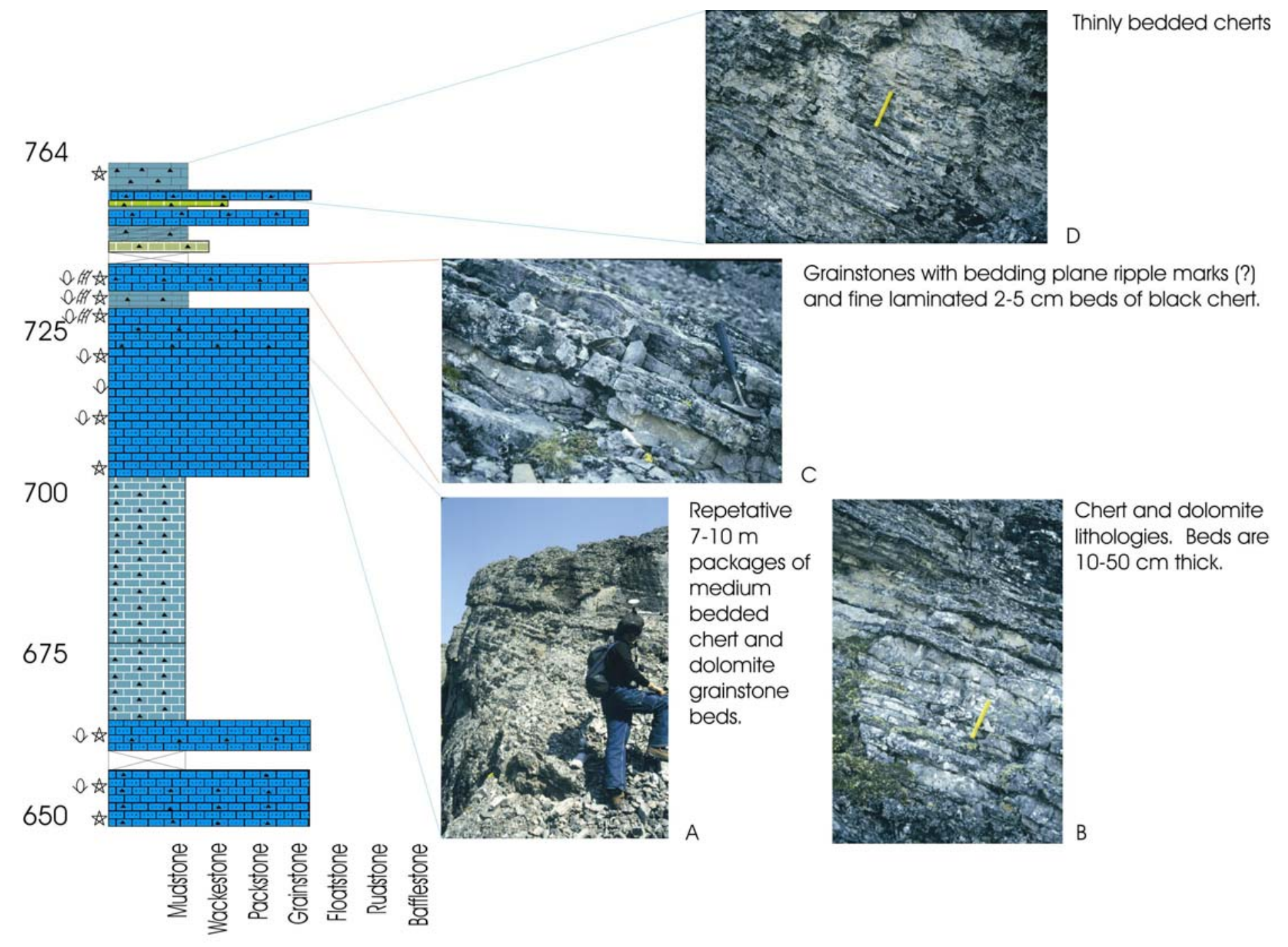

Fig. 8: Lower Middle Alapah Limestone 


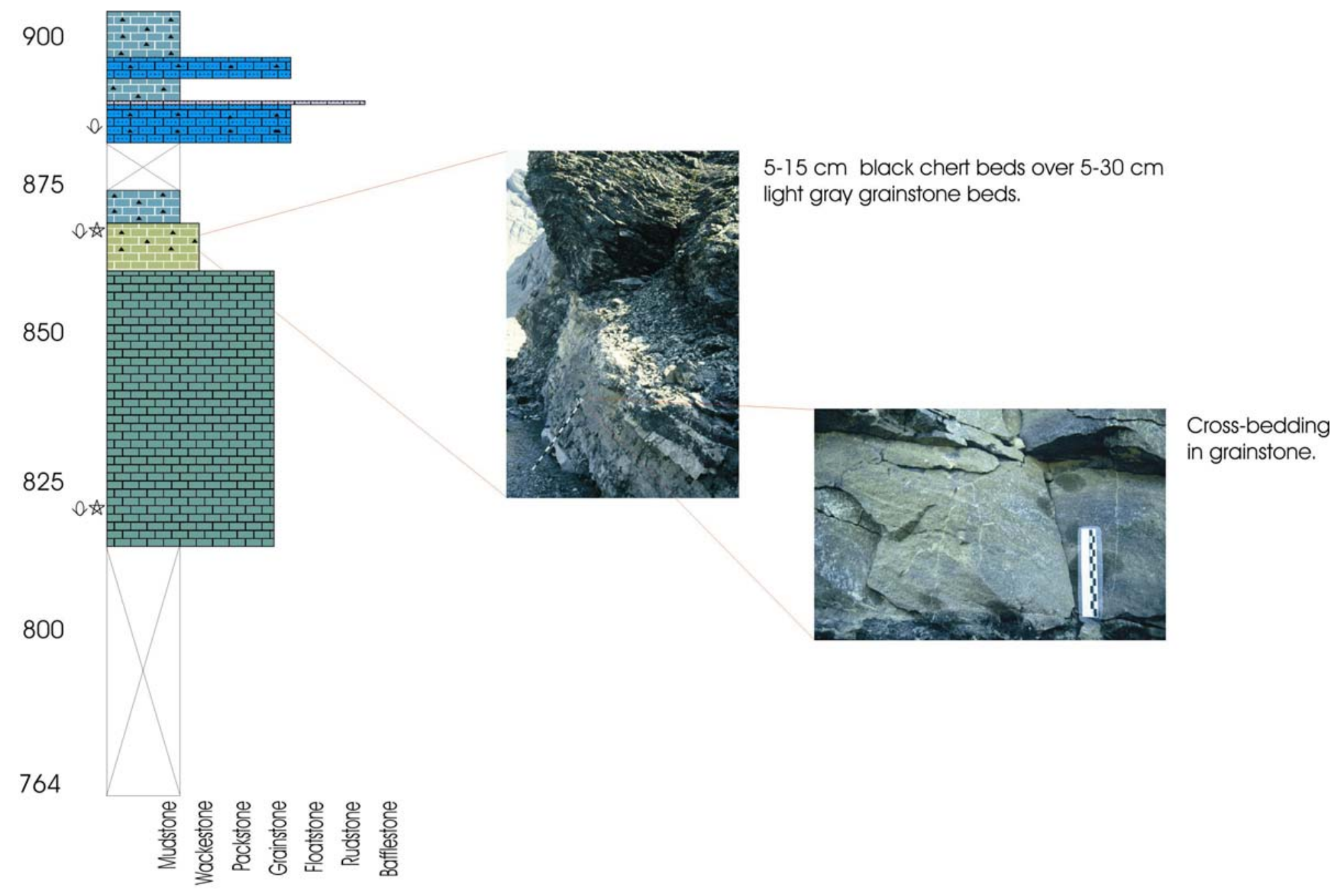

Fig. 9: Middle Alapah Limestone 


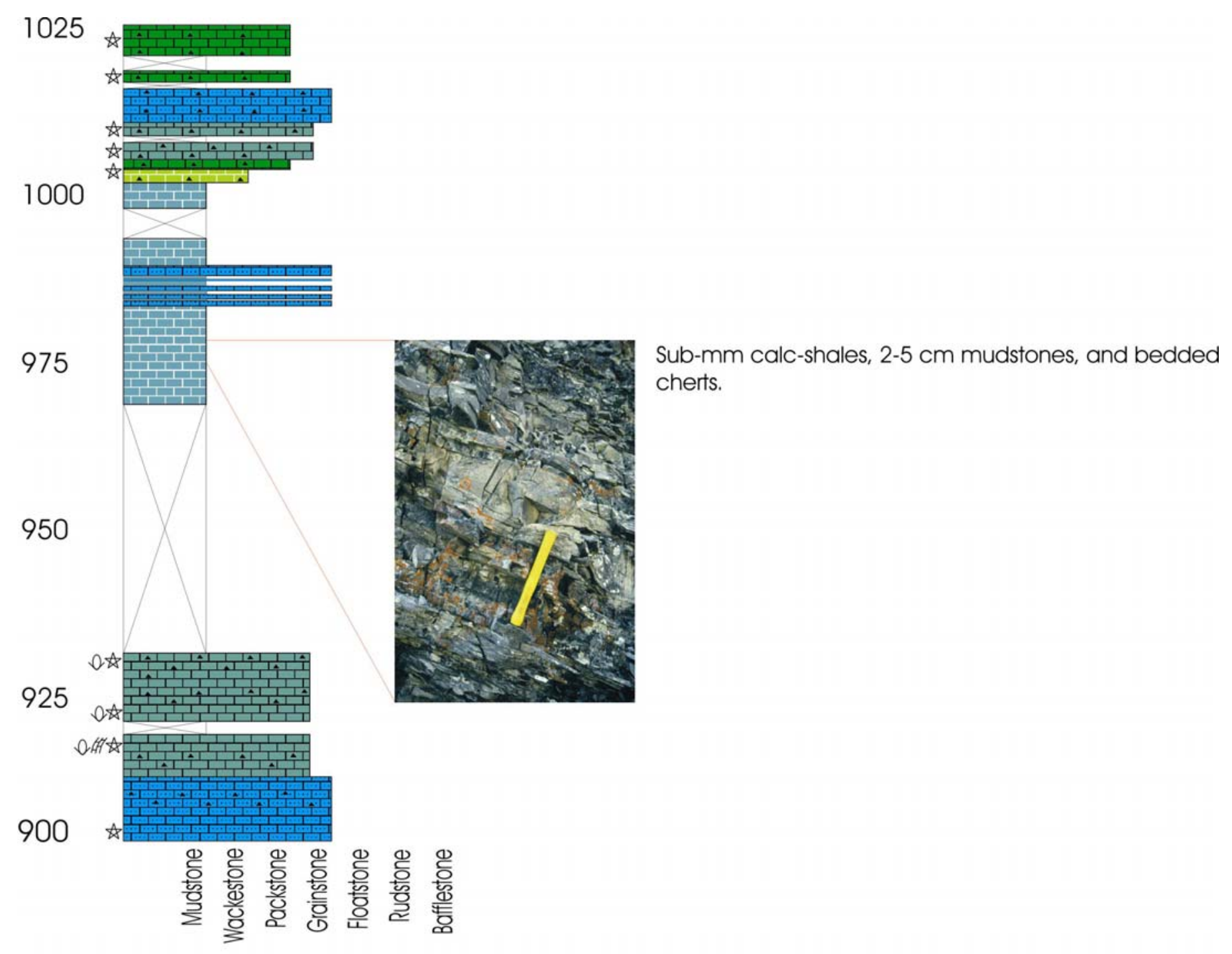

Fig. 10: Middle Alapah 


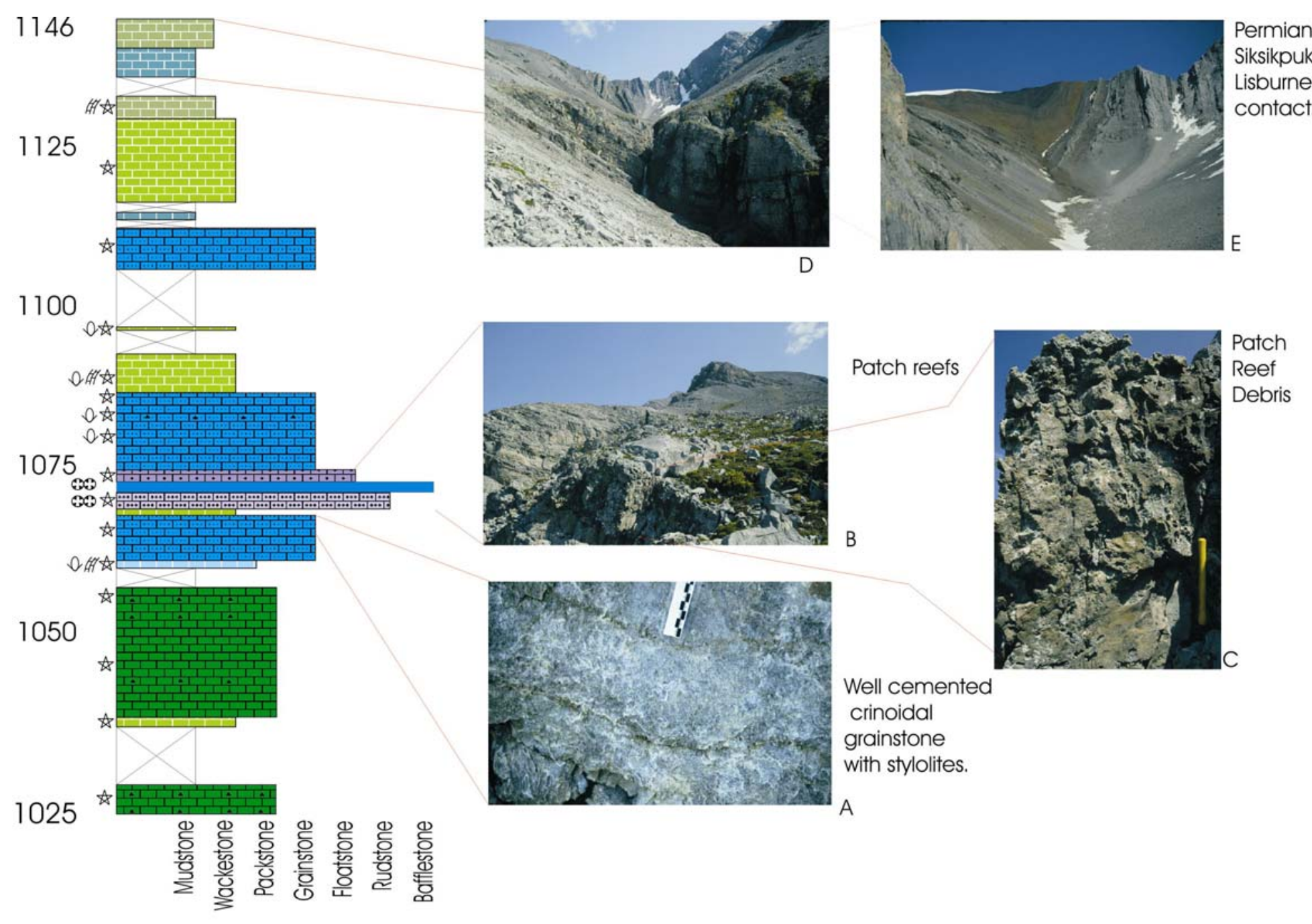

Fig. 11: Middle Upper Alapah (end of measured section) 

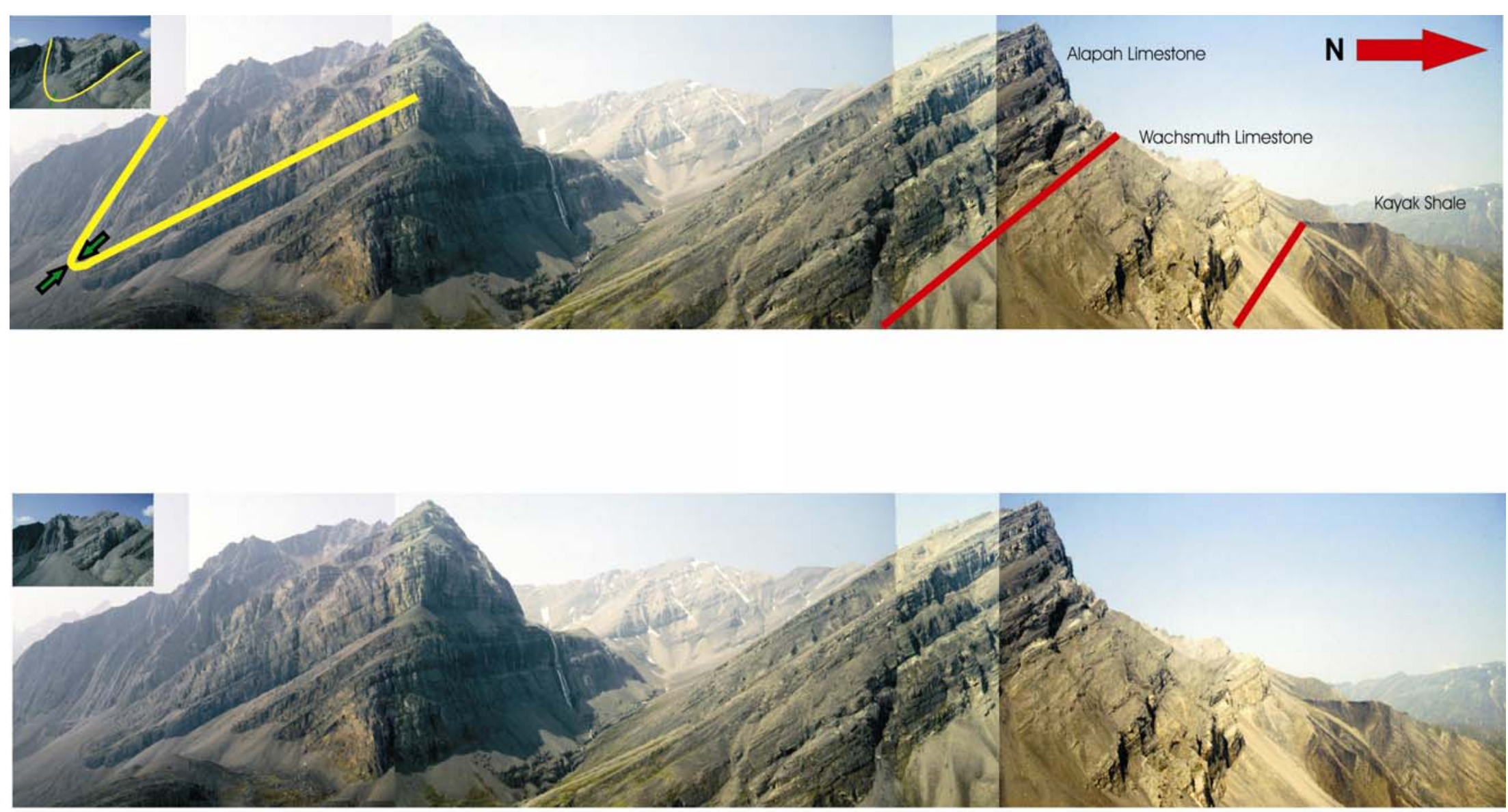

Fig. 12: Lisburne Group and Upper Endicott Group, Nanushuk River. View is to the west. Stratigraphic boundaries are red and structure is indicated with yellow. 

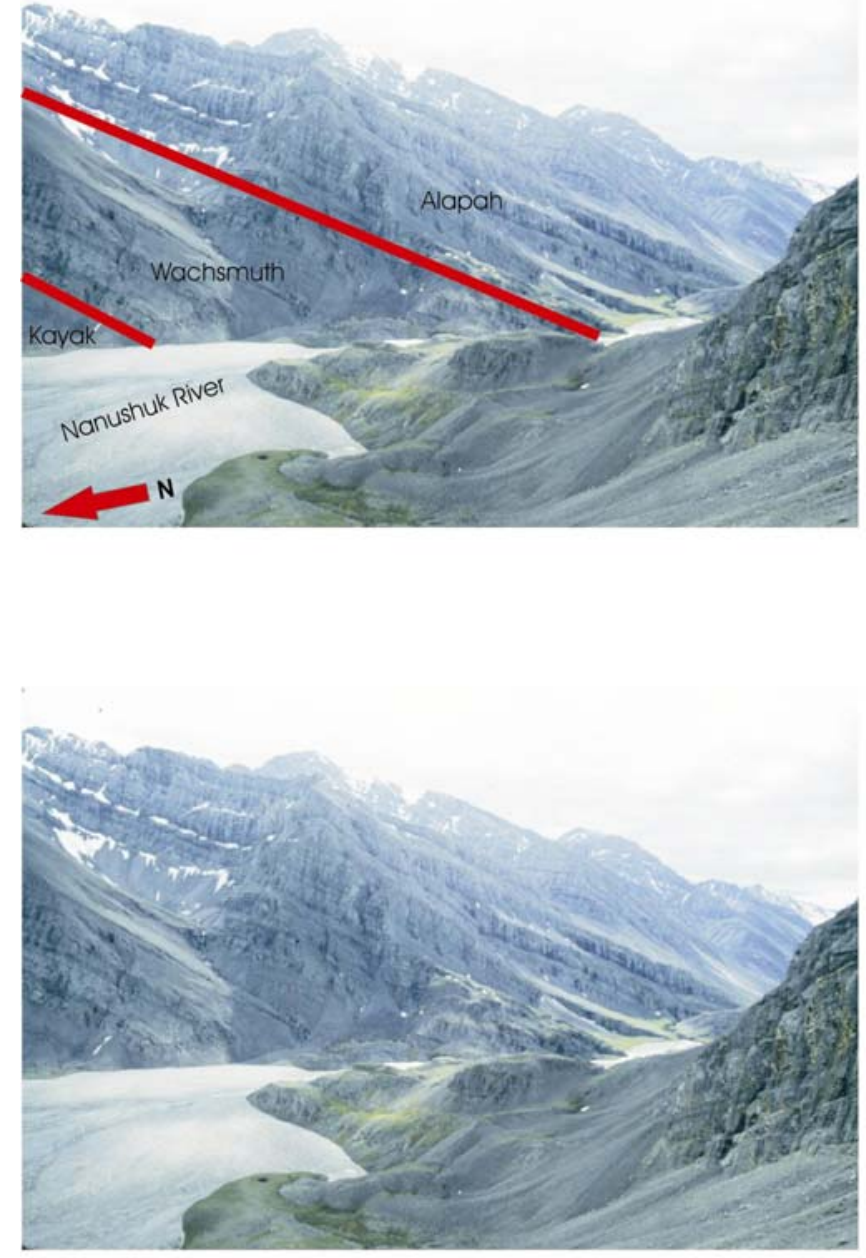

Fig. 13: Lisburne Group and Upper Endicott Group, Nanushuk River. View is to the southeast. Stratigraphic boundaries are red.
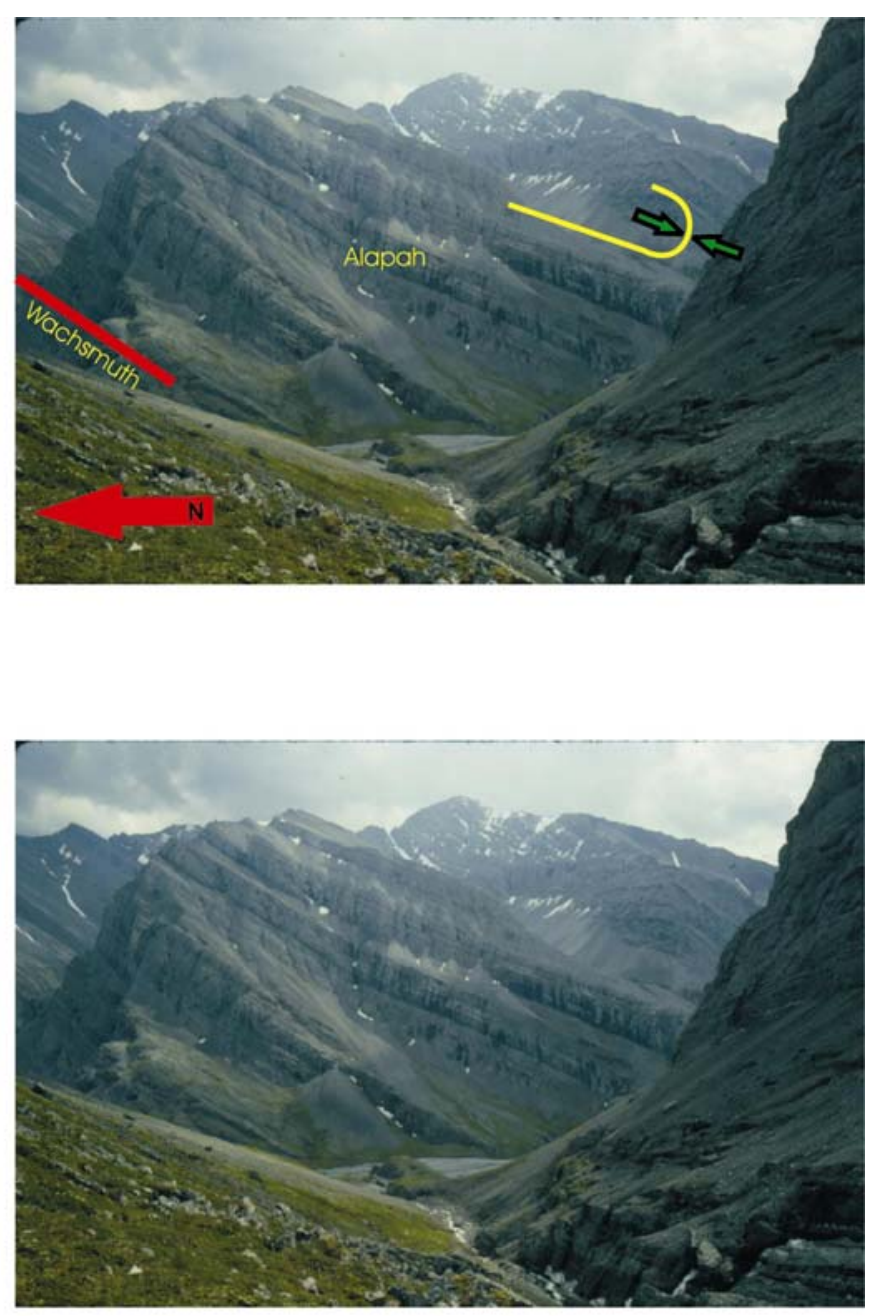

Fig. 14: Lisburne Group Nanushuk River. View is to the east. Stratigraphic boundaries are red, structures are yellow. 

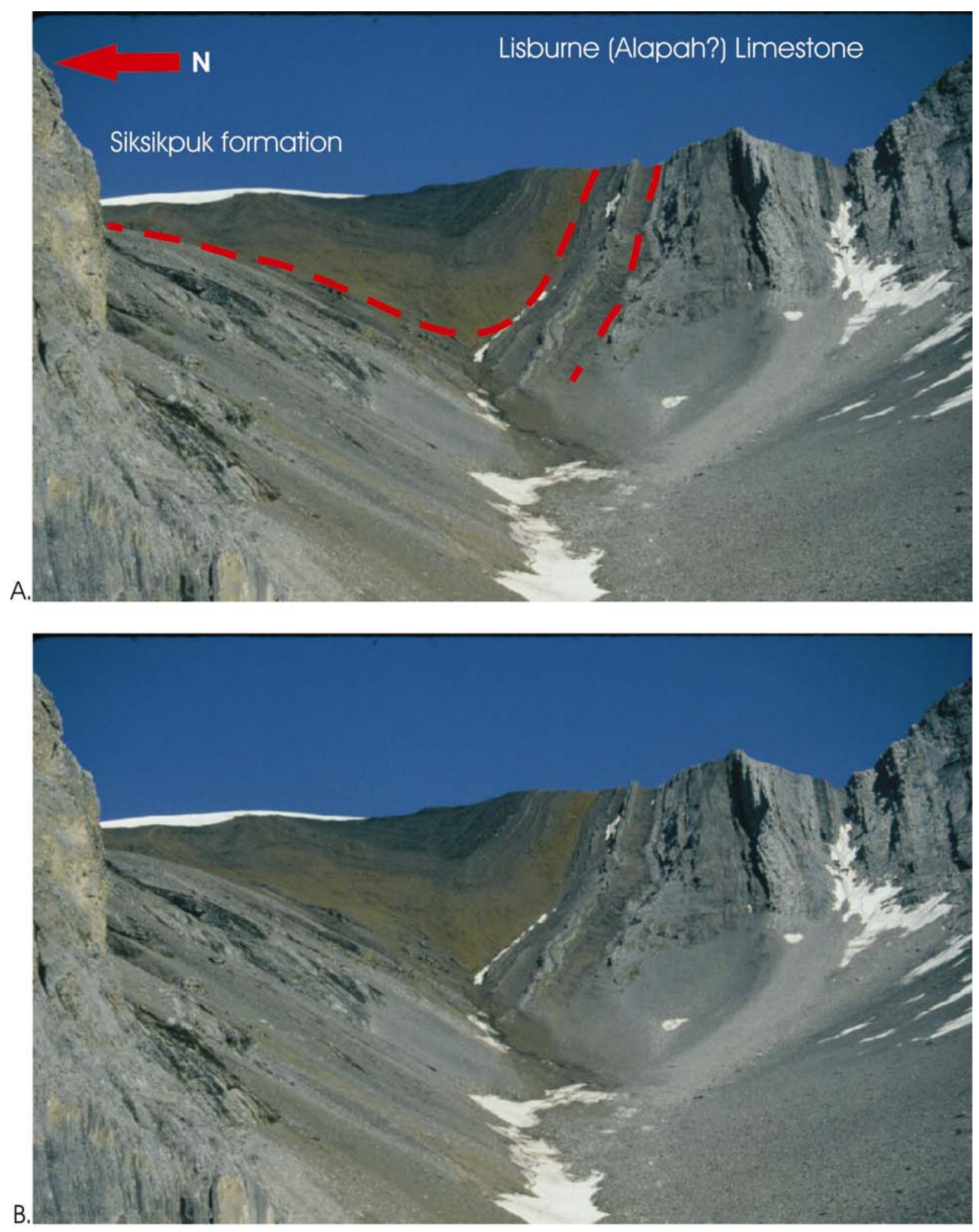

Fig. 15: Lisburne Limestone and Permian Siksikpuk transitional contact in syncline on Cockedhat Mountain. Oblique view to the east. 